\title{
Realitas Virtual untuk Belajar Kosa Kata Bahasa Asing Menggunakan Teknologi Google Cardboard
}

\author{
Devira Wiena Pramintya, Darlis Herumurti, dan Anny Yuniarti \\ Departemen Teknik Informatika, Fakultas Teknologi Informasi, Institut Teknologi Sepuluh Nopember \\ (ITS) \\ e-mail: darlis@if.its.ac.id
}

\begin{abstract}
Abstrak-Penguasaan bahasa asing yang baik merupakan salah satu akses untuk meraih keberhasilan dalam berbagai bidang. Pada abad ke-21 ini, sebanyak 23 bahasa menjadi bahasa ibu sebagian besar penduduk dunia. Bahasa-bahasa itu beberapa di antaranya adalah Inggris, Mandarin, Spanyol, Portugis, Perancis, Rusia, Bahasa Indonesia, Hindi, Arab, Italia, Bahasa Jawa, Jerman, Korea, dan Jepang, dimana Bahasa Mandarin menjadi bahasa urutan pertama yang banyak digunakan. Pengajaran bahasa biasanya terdapat empat bidang keterampilan yang dijadikan acuan kurikulum yaitu mendengarkan, membaca, berbicara, dan menulis. Saat ini teknologi informasi dan komunikasi hadir dalam semua aspek kehidupan. Realitas virtual dapat menjadi solusi yang tepat untuk menangani permasalahan tersebut. Dengan dibangunnya aplikasi Realitas Virtual untuk Belajar Kosa Kata Bahasa Asing Menggunakan Google Cardboard, pengguna dapat berinteraksi dengan suatu lingkungan yang disimulasikan oleh komputer dan dengan tambahan alat Google Cardboard pengguna semakin merasakan seperti sedang mencari objek-objek tersebut pada dunia nyata. Selain itu, pengguna juga mendapat pengetahuan kosa kata baru dari nama-nama objek-objek tersebut dalam berbagai bahasa yang diberikan oleh aplikasi yaitu Bahasa Inggris, Bahasa Arab, dan Bahasa Jepang. Berdasarkan pengujian aplikasi menggunakan hasil kuesioner responden dapat diketahui bahwa penilaian kenyamanan antarmuka oleh penguji mencapai $58,3 \%$, kemiripan objek mencapai 79,1\%, kegunaan informasi mencapai $91,6 \%$, performa sistem mencapai nilai $75 \%$ dan perasaan immersive mencapai nilai $91,6 \%$. Dengan dikembangkannya aplikasi ini, diharapkan dapat membantu untuk belajar mengenal kosa kata benda dalam berbagai bahasa asing.
\end{abstract}

Kata Kunci-Bahasa, cardboard, realitas virtual.

\section{PENDAHULUAN}

$\mathrm{P}$ ENGUASAAN bahasa asing yang sedang dominan dalam pergaulan internasional, merupakan salah satu akses untuk meraih keberhasilan dalam berbagai bidang. Menurut laporan UNESCO pada multibahasa, bahasa merupakan media penting untuk pemenuhan hak-hak dasar, seperti ekspresi, pendidikan politik dan partisipasi dalam masyarakat (Direktorat Jenderal UNESCO, 2007) [1]. Pada abad ke-21 ini, seorang desainer dari South China Morning Post yaitu Alberto Lucas Lopez pernah membuat gambar cantik yang menunjukkan infografis secara jelas bahasa apa saja yang paling banyak digunakan oleh milyaran penduduk bumi saat ini. Infografis ini sendiri dibuat berdasarkan data dari Ethnologue dan diperkirakan saat ini setidaknya terdapat 7.102 bahasa yang sudah diidentifikasi. Sebanyak 23 bahasa merupakan bahasa pokok yang menjadi bahasa ibu sebagian besar penduduk dunia. Bahasa-bahasa itu beberapa di antaranya adalah Inggris, Mandarin, Spanyol, Portugis, Perancis, Rusia, Bahasa Indonesia, Hindi, Arab, Italia, Bahasa Jawa, Jerman, Korea, dan Jepang. Peringkat pertama sendiri diduduki oleh Bahasa Mandarin [2]. Pengajaran bahasa asing di Indonesia juga mengalami berbagai perubahan seperti yang Anita Lie tuturkan bahwa dalam pengajaran bahasa, biasanya ada empat bidang keterampilan yang dijadikan acuan kurikulum yaitu mendengarkan, membaca, berbicara, dan menulis [3].

Saat ini, teknologi informasi dan komunikasi hadir dalam semua aspek kehidupan. Sistem pendidikan seharusnya tidak mengabaikan sumber daya baru multimedia [1]. Realitas virtual menjadi solusi yang ada untuk menangani permasalahan tersebut. Realitas virtual adalah teknologi yang membuat pengguna dapat berinteraksi dengan suatu lingkungan yang disimulasikan oleh komputer (computer simulated environment) [4]. Selain itu, realitas virtual ini juga dikembangkan dengan tambahan alat Google Cardboard agar pengguna semakin merasakan seperti sedang mencari objekobjek tersebut pada dunia nyata. Hal itu dikarenakan cardboard mudah didapatkan dan hanya membutuhkan smartphone untuk melakukan proses rendering objek 3D. Fitur dari smartphone dapat digunakan dalam pendidikan sehingga pembuatan aplikasi ini dengan memanfaatkan smartphone dan tambahan alat Google Cardboard dinilai sesuai.

Dengan aplikasi ini, pengguna mendapatkan pengalaman untuk mencari objek-objek pada sebuah tempat atau lokasi untuk yang muncul dengan gambaran yang lebih jelas. Hal ini dikarenakan objek-objek yang ada divisualisasikan dalam objek 3D. Selain itu, pengguna juga mendapat pengetahuan kosa kata baru dari nama-nama objek-objek tersebut dalam berbagai bahasa.

\section{TINJAUAN PUSTAKA}

\section{A. Pemodelan 3D Mobile}

Model 3D dan animasi 3D kebanyakan digunakan pada perangkat desktop karena mempunyai spesifikasi hardware yang lebih tinggi dibandingkan dengan perangkat bergerak (mobile). Perangkat mobile mempunyai konfigurasi hardware yang rendah dan tergolong dalam Low Cost Access Devices 
(LCADs) sehingga memerlukan pemodelan 3D dengan metode low poly. Hal tersebut dikarenakan tidak adanya Graphic Accelerator pada perangkat LCADs. Pemodelan 3D dengan metode low poly dapat mengurangi ukuran file, mesh-density, dan waktu loading objek 3D pada perangkat mobile [5].

\section{B. Realitas Virtual}

Realitas virtual atau Virtual Reality (VR) adalah suatu teknologi yang memberi interaksi grafis secara langsung (realtime) dengan model tiga dimensi yang dikombinasikan dengan teknologi layar yang mampu memberi kesan immersive (seolah-olah berada pada dunia nyata) kepada pengguna. Realitas Virtual pada dasarnya mengacu pada kesan immersive, interaktif, multi-sensor, pengolahan komputer yang menghasilkan lingkungan tiga dimensi dan kombinasi teknologi yang dibutuhkan untuk membangun lingkungan tersebut. Realitas virtual memungkinkan untuk menyimulasikan dunia nyata ke dalam sistem visualisasi tiga dimensi dan memungkinkan interaksi pengguna dengan model karena kemampuan pelacakan gerak dan kemampuan untuk bertindak dengan produk secara real time [6].

\section{House of Language}

House of Language adalah sebuah aplikasi virtual reality dengan teknologi Gear VR untuk belajar bahasa. Aplikasi ini efektif untuk belajar kosa kata baru menggunakan beberapa saluran persepsi di VR seperti melihat objek dan nama yang sesuai, mendengar nama objek, dan ulangi nama objek [7]. Aplikasi buatan Estonia-based Fox3D Games menempatkan permainan pada pengalaman di sebuah rumah kartun dengan hewan rakun lucu untuk belajar bahasa Spanyol, Jerman atau Inggris. Mr. Woo adalah guru rakun dan gambar benda muncul di atas kepalanya seperti gelembung pikiran kemudian pengguna harus melihat sekeliling ruangan untuk menemukan benda tersebut [7]. Aplikasi ini menggunakan teknologi Gear VR yang hanya dapat berjalan pada smartphone Galaxy milik Samsung dan dijual dengan harga 1.500.000 [8]. Sehingga aplikasi ini tidak dapat digunakan oleh semua kalangan masyarakat karena bergantung dengan handphone yang digunakan dan harga Gear VR sendiri terbilang masih cukup mahal.

\section{Bahasa Asing}

Penguasaan bahasa Asing yang sedang dominan dalam pergaulan internasional, merupakan salah satu akses untuk meraih keberhasilan dalam berbagai bidang. Menurut laporan UNESCO pada multibahasa, bahasa merupakan media penting untuk pemenuhan hak-hak dasar, seperti ekspresi, pendidikan politik dan partisipasi dalam masyarakat (Direktorat Jenderal UNESCO, 2007) [1]. Pada abad ke-21 ini, seorang desainer dari South China Morning Post yaitu Alberto Lucas Lopez menunjukkan infografis penggunaan bahasa di seluruh dunia. Diperkirakan saat ini setidaknya terdapat 7.102 bahasa yang sudah diidentifikasi. Sebanyak 23 bahasa merupakan bahasa pokok yang menjadi bahasa ibu sebagian besar penduduk dunia. Bahasa-bahasa itu beberapa di antaranya adalah Inggris, Mandarin, Spanyol, Portugis, Perancis, Rusia, Bahasa Indonesia, Hindi, Arab, Italia, Bahasa Jawa, Jerman, Korea, dan Jepang [2]. Pengajaran bahasa asing di Indonesia juga mengalami berbagai perubahan seperti yang Anita Lie tuturkan bahwa dalam pengajaran bahasa, biasanya ada empat bidang keterampilan yang dijadikan acuan kurikulum: mendengarkan, membaca, berbicara, dan menulis [3].

\section{E. Edukasi Anak}

Pakar psikologi anak, Seto Mulyadi atau yang lebih dikenal dengan sapaan Kak Seto, menilai pengajaran bahasa asing kepada anak sejak usia dini sah-sah saja. Namun dilakukan dengan metode yang menyenangkan dan penuh persahabatan serta mempertimbangkan kepentingan dan kepribadian anak saat memutuskan topik untuk mengajar [9].

Anak-anak yang berada pada usia 7-12 tahun, secara psikologis sedang pada masa emas untuk belajar bahasa selain bahasa ibu. Karena area pada otak yang mengatur kemampuan berbahasa terlihat mengalami critical periods dan kemampuan anak dalam proses kognitif, kreativitas, dan divergent thinking berada pada kondisi optimal. Berdasarkan hasil riset teknologi brain imaging University of California, Los Angeles, secara biologis anak usia tersebut menjadi waktu yang tepat untuk belajar bahasa asing. Anak-anak yang belajar bahasa asing mempunyai kemampuan lebih dalam tugas memori episodic, mempelajari kalimat dan kata, memori semantik, kelancaran menyampaikan pesan dan mengkategorikannya.

Edukasi bahasa dapat diimplementasikan melalui mainan edukatif seperti terdapat benda berbentuk kotak, segiempat, bulat dengan berbagai warna; biru, merah, hijau, dan lain sebagainya. Permainan edukatif juga harus mempunyai fungsi untuk mengembangkan berbagai aspek perkembangan anak, seperti motorik, bahasa, kecerdasan, dan sosialisasi. Selain itu alat permainan edukatif harus dapat dimainkan dengan berbagai variasi, tetapi jangan terlalu sulit agar tidak frustasi, atau terlalu mudah sehingga anak akan cepat bosan. Terdapat syarat-syarat yang perlu diperhatikan dalam memilih permainan edukatif diantaranya memiliki desain mudah dan sederhana, sesuai untuk anak lelaki atau perempuan, mampu memotivasi anak dan tidak memerlukan pengawasan yang intensif, tahan lama dan sesuai tujuan yang diinginkan, sesuai kebutuhan dan tidak menghabiskan ruangan, dan diharapkan mampu mengembangkan daya fantasi dan imajinasi anak [10].

Walaupun alat permainan edukatifnya sederhana harus tetap menarik. Bila bersuara, suaranya harus jelas. Alat permainan edukatif harus mudah diterima oleh semua kebudayaan karena bentuknya sangat umum, pemeliharaannya mudah, terbuat dari bahan yang mudah didapat, dan harganya terjangkau oleh masyarakat luas.

\section{F. Google Cardborad}

Google Cardboard adalah teknologi penampilan realitas virtual yang berupa Head Mounted Displays (HMD). Fungsi dari perangkat keras ini adalah sebagai alat bantu untuk memainkan aplikasi atau game VR. Google Cardboard bekerja baik dengan berbagai resolusi smartphone [11]. Pihak pengembang Google Cardboard juga telah menyertakan Software Development Kit (SDK) yang berisi modul-modul pembantu untuk mempermudah pembuatan aplikasi yang berbasis Google Cardboard. SDK ini berisi berbagai modul kode sumber yang dapat langsung digunakan oleh pengembang. SDK Google Carboard dapat digunakan dengan berbagai 
aplikasi lain seperti Unity, Android Studio, dll.

\section{DESAIN SISTEM}

\section{A. Perancangan Data}

Perancangan data merupakan hal yang diperlukan dalam memilih dan menyusun sistem agar tepat dan dapat beroperasi secara benar. Data yang diperlukan dalam pengoperasian perangkat lunak, yaitu meliputi objek-objek berupa bendabenda yang biasa ditemukan sehari-sehari seperti pada ruang kamar tidur, kamar mandi, dapur, dan ruang keluarga atau ruang tamu. Serta audio dari pengucapan nama-nama yang sesuai dengan objek-objek benda tersebut. Data mengenai benda-benda tersebut diambil dari berbagai sumber di internet tentang edukasi anak dan aplikasi yang hampir mirip dan data mengenai desain ruang didapat dari foto dan video. Sedangkan data audio dari pengucapan nama-nama benda dalam berbagai bahasa asing tersebut didapatkan dari halaman web Sound of Text yang memberikan fitur untuk mengunduh audio file .mp3 dari Google Translate.

\section{B. Perancangan Model $3 D$}

Perancangan model dibuat menggunakan Blender versi 2.76b. Terdapat 102 objek benda yang dimodelkan dan diletakkan di berbagai lokasi ruang meliputi ruang kamar tidur, kamar mandi, dapur, dan ruang keluarga atau ruang tamu. Perancangan model dari awal dilakukan dengan mengumpulkan informasi suatu benda yang akan dibuat dengan cara mengamati secara langsung suatu benda tersebut atau dengan melihat gambar. Kemudian didesain dan dimodelkan ke Blender. Setelah model jadi, lalu model diberi tekstur untuk bisa diolah di Unity.

Selain itu perancangan model objek-objek benda dapat dilakukan dengan cara perancangan ulang model 3D yang sudah ada. Model yang sudah dirancang dilakukan pengecekan ulang untuk pengoptimalan jumlah poligon (mesh). Caranya yaitu menghilangkan bagian yang tidak utama dari objek. Kemudian bagian yang dihilangkan diganti dengan pemberian tekstur yang berbeda. Setelah pengecekan ulang selesai, dilakukan juga perancangan ulang pada model yang dibuat dari awal oleh penulis. Perancangan ulang ini dilakukan supaya mendapatkan model low poly. Perancangan model low poly tentunya tidak melupakan aspek kemiripan dengan aslinya. Tujuan dirancangnya model low poly ini adalah untuk mengurangi beban kerja processor perangkat bergerak.

\section{Perancangan Proses}

Tahap perancangan proses dibagi menjadi empat bagian, yaitu:

\section{Proses Tampilkan Nama Objek Benda Yang Dicari}

Menampilkan nama objek benda yang harus dicari oleh pengguna membutuhkan area untuk menampilkan nama objek benda tersebut dan trigger yang digunakan untuk menampilkan nama objek tersebut. Trigger pertama kali aktif setelah dua detik memasuki aplikasi dan kemudian akan aktif kembali jika benda yang sesuai dengan nama yang ditampilkan telah ditemukan, sehingga akan tampil nama objek benda baru yang berbeda dengan sebelumnya.

\section{Proses Penghitungan Poin}

Penghitungan poin dibutuhkan untuk memberi informasi kepada pengguna bahwa objek benda yang ditemukan sesuai dengan perintah atau tidak sesuai dengan perintah. Poin akan bertambah jika benda yang ditemukan sesuai dan poin akan tetap jika benda yang ditemukan pengguna tidak sesuai.

\section{Proses Penghitungan Waktu}

Penghitungan waktu digunakan untuk memberikan batas waktu kepada pengguna saat sedang mencari objek - objek benda yang diperintahkan sehingga pengguna tidak akan bosan. Batas waktu yang diberikan berbeda-beda pada setiap ruang. Jika waktu yang diberikan telah habis dan pengguna belum menemukan objek benda yang diperintahkan, maka pengguna dianggap belum berhasil dan diberikan kesempatan untuk mengulangi lagi.

\section{Proses Pemutaran Audio}

Pemutaran audio dibutuhkan agar pengguna mengetahui cara pengucapan suatu benda dalam bahasa asing. Audio akan pengucapan suatu benda diputar ketika menampilkan nama benda tersebut yang harus ditemukan oleh pengguna dan ketika pengguna berhasil menemukan objek benda yang diminta. Selain itu, ketika pengguna menemukan objek benda yang tidak sesuai dengan perintah maka akan diputar audio untuk mencari kembali benda yang sesuai.

\section{Deskripsi Perangkat Lunak}

Studi ini berbentuk realitas virtual dan diperuntukkan pada sistem operasi android, di mana pengguna harus menggunakan pada perangkat bergerak dengan sistem android versi 4.1 atau lebih tinggi yang dilengkapi dengan sensor Accelerometer dan sensor Gyroscope. Perangkat lain yang dibutuhkan adalah kacamata VR (Virtual Reality) dan controller agar dapat memberi rasa immersive yang lebih baik. Pengguna utama dari aplikasi ini adalah anak-anak di rentang usia 7-12 tahun karena secara psikologis sedang pada masa emas untuk belajar bahasa selain bahasa ibu. Pengguna dapat memilih bahasa asing yang ingin dipelajari yaitu Bahasa Inggris, Bahasa Arab, dan Bahasa Jepang. Objek-objek benda di dalam aplikasi ini dibuat sedemikian rupa hingga menyerupai aslinya. Terdapat juga objek tambahan yang tidak ada pada kondisi aslinya, yaitu ketika pengguna berhasil menemukan objek benda yang sesuai dengan nama yang disebutkan, objek benda tersebut akan memutarkan audio pengucapan nama benda tersebut sesuai bahasa yang dipilih sebelumnya. Selain itu, jika pengguna gagal memilih benda yang sesuai sebanyak tiga kali maka akan muncul hint (bantuan petunjuk jawaban benda yang sesuai dengan perintah berupa tanda panah).

\section{E. Perancangan Sistem}

Tahap perancangan dalam subbab ini dibagi menjadi beberapa bagian yaitu perancangan diagram kasus penggunaan, perancangan spesifikasi skenario kasus penggunaan, perancangan antarmuka pengguna, perancangan skenario pencarian kata, perancangan level pada aplikasi, dan perancangan kontrol aplikasi. Rancangan kasus penggunaan dapat dilihat pada Gambar 1. 


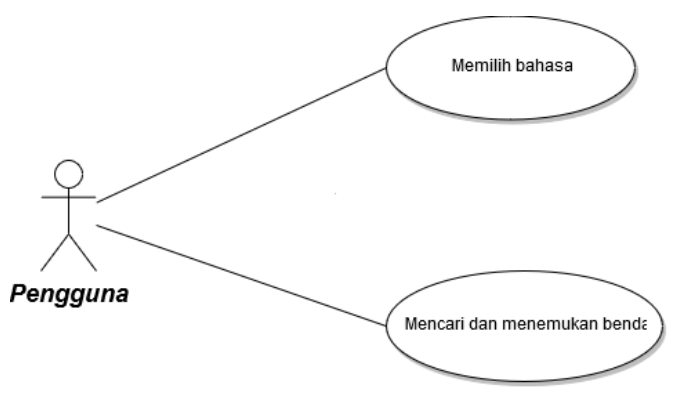

Gambar 1. Diagram Kasus Pengunaan

Penjelasan singkat dari masing-masing kasus penggunaan dapar dilihat pada Tabel 1.

Tabel 1.

Skenario Kasus Pengguna

\begin{tabular}{|c|c|c|c|}
\hline No & $\begin{array}{l}\text { Kode Kasus } \\
\text { Penggunaan }\end{array}$ & $\begin{array}{l}\text { Nama Kasus } \\
\text { Penggunaan }\end{array}$ & Keterangan \\
\hline 1 & UC-001 & Memilih bahasa & $\begin{array}{l}\text { Pengguna dapat } \\
\text { memilih bahasa asing } \\
\text { yang diinginkan }\end{array}$ \\
\hline 2 & UC-002 & $\begin{array}{l}\text { Mencari dan } \\
\text { menemukan } \\
\text { benda }\end{array}$ & $\begin{array}{l}\text { Pengguna } \\
\text { mendapatkan } \\
\text { informasi pengucapan } \\
\text { dan penulisan nama } \\
\text { benda dari perintah } \\
\text { yang diberikan }\end{array}$ \\
\hline
\end{tabular}

Aplikasi ini akan dibangun dengan mode normal untuk menu utama dan mode First Person Camera (FPS). Objek yang ditampilkan sesuai scene masing-masing. Rancangan dari antarmuka aplikasi ini terdapat pada Gambar 2.

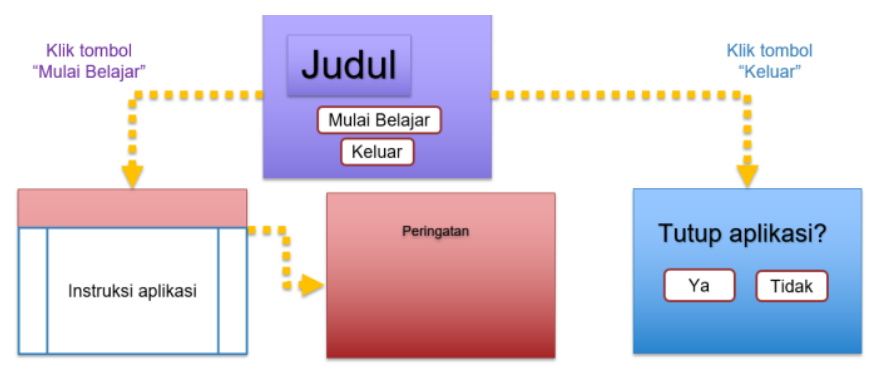

Gambar 2. Rancangan Antarmuka Menu Utama

\section{IMPLEMENTASI}

Pada bab ini akan dibahas mengenai implementasi dari perancangan perangkat lunak. Di dalamnya mencakup proses penerapan dan pengimplementasian proses dan antarmuka yang mengacu pada rancangan yang telah dibahas.

\section{A. Lingkungan Implementasi}

Lingkungan implementasi dijelaskan pada Tabel 2.

Tabel 2.

Lingkungan Implementasi Perangkat Lunak

\begin{tabular}{ll}
\hline \hline Perangkat & Pengembangan Aplikasi \\
Keras & Prosesor : Intel(R) Core(TM) i5-5200U CPU @ 2.7GHz \\
& Memori : 4 GB \\
& Implementasi Aplikasi \\
& Prosesor: Mediatek MT6752 Octa-core 1.7 GHz Cortex- \\
& \multicolumn{1}{c}{ A53 } \\
\hline \hline
\end{tabular}

\begin{tabular}{ll}
\hline \hline & Memori : 2 GB \\
Perangkat & Sistem Operasi : \\
Lunak & - Windows 10 64 bit (Pengembangan) \\
& - Android 6.0.1 (Implementasi) \\
& Perangkat Pengembang : \\
& - Blender 2.76b \\
& - Unity 5.5.2f1 \\
& - MonoDevelop v5.9.6 \\
\hline \hline
\end{tabular}

\section{B. Implementasi Pembuatan Objek 3D}

Terdapat 102 objek 3D benda yang diimplementasikan dimana ada 79 objek 3D benda yang dibuat dari awal dan 29 objek 3D benda yang dimodifikasi. Implementasi pembuatan objek 3D dari awal dilakukan dengan mengamati secara langsung benda yang akan dimodelkan atau dengan melihat gambar. Kemudian dilakukan pemberian tekstur yang disesuaikan dengan objek aslinya. Selain membuat model dari awal, juga dilakukan modifikasi poligon model yang diunduh dari halaman web di http://www.tf3dm.com. Modifikasi model yaitu dengan menganalisis vertex, edge, dan face yang dapat dilakukan dengan modifier tools yang ada pada Blender sehingga model menjadi low poly. Model 3D yang dibuat dari awal juga dilakukan modifikasi model. Ketika seluruh objek 3D sudah selesai dirubah ke low poly maka objek diekspor dalam ekstensi .fbx karena mempunyai ukuran file yang lebih kecil dibandingkan .blend. yang menyebabkan kemudahan dalam proses render dan tidak memberatkan aplikasi. Bab ini dibagi ke dalam empat subbab meliputi Implementasi Model di Ruang Kamar Tidur, Implementasi Model di Ruang Kamar Mandi, Implementasi Model di Ruang Dapur, dan Implementasi Model di Ruang Keluarga atau Ruang Tamu.

\section{Implementasi Pembuatan Aplikasi}

Pada tahap implementasi pembuatan aplikasi ini, akan dibagi ke dalam sepuluh subbab. Kesepuluh subbab tersebut yaitu meliputi Implementasi Antarmuka Menu, Implementasi Realitas Virtual dengan Cardboard, Implementasi Pembuatan Scene, Implementasi Import Assets, Implementasi Load Objek ke Scene, Implementasi Penambahan Audio, Implementasi Pembuatan Script, Implementasi Kontrol Aplikasi, Implementasi Menampilkan Nama Objek Benda, dan Implementasi Level Aplikasi. Untuk tampilan antarmuka aplikasi dapat dilihat pada Gambar 3.

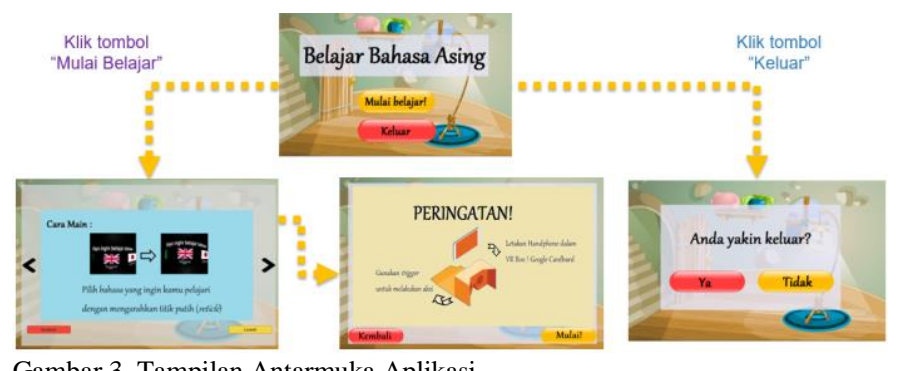

\section{PENGUJIAN DAN EVALUASI}

Bab ini membahas mengenai uji coba dan evaluasi aplikasi. Uji coba ini digunakan untuk menguji baik dari sisi perangkat lunak dan perangkat keras. 


\section{A. Pengujian Fungsionalitas}

Pengujian fungsionalitas aplikasi ini dilakukan secara mandiri yang bertujuan untuk mengetahui kesesuaian keluaran dari tiap tahap dan langkah penggunaan fitur terhadap skenario yang dipersiapkan. Skenario dan hasil pengujian dapat dilihat pada Tabel 3. Contoh uji fungsionalitas ditunjukan pada Gambar 4, Gambar 5, Gambar 6, Gambar 7, dan Gambar 8.

Tabel 3.

Skenario dan Hasil Pengujian Fungsionalitas

\begin{tabular}{|c|c|c|c|}
\hline \multirow{3}{*}{$\begin{array}{l}\text { Kode } \\
\text { UJ-UC- } \\
001\end{array}$} & \multicolumn{2}{|c|}{ Uji Coba } & Hasil \\
\hline & Uji Memilih Bahasa & Skenario 1 & Berhasil \\
\hline & & Skenario 2 & Berhasil \\
\hline $\begin{array}{l}\text { UJ-UC- } \\
002\end{array}$ & $\begin{array}{l}\text { Uji Mencari dan } \\
\text { Menemukan Benda }\end{array}$ & $\begin{array}{l}\text { Skenario } 1 \\
\text { Skenario } 2\end{array}$ & $\begin{array}{l}\text { Berhasil } \\
\text { Berhasil }\end{array}$ \\
\hline
\end{tabular}

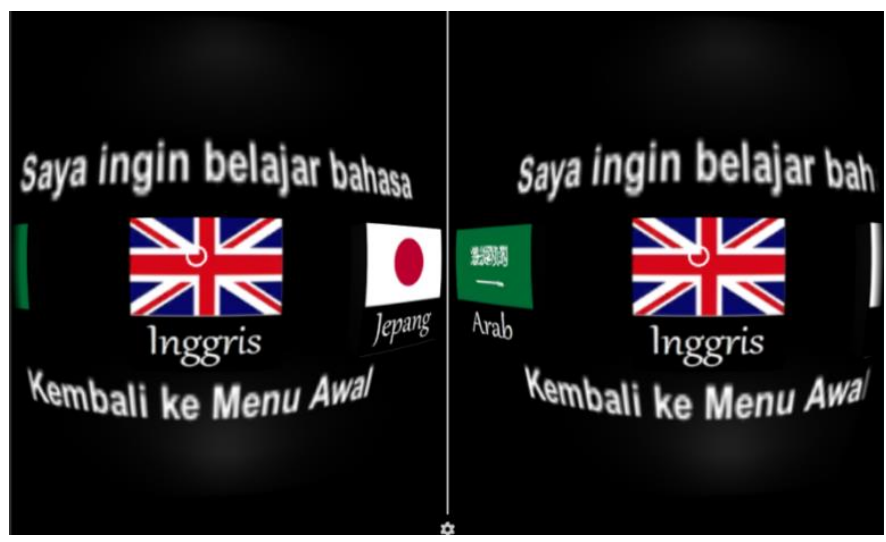

Gambar 4. Tampilan Uji Memilih Bahasa

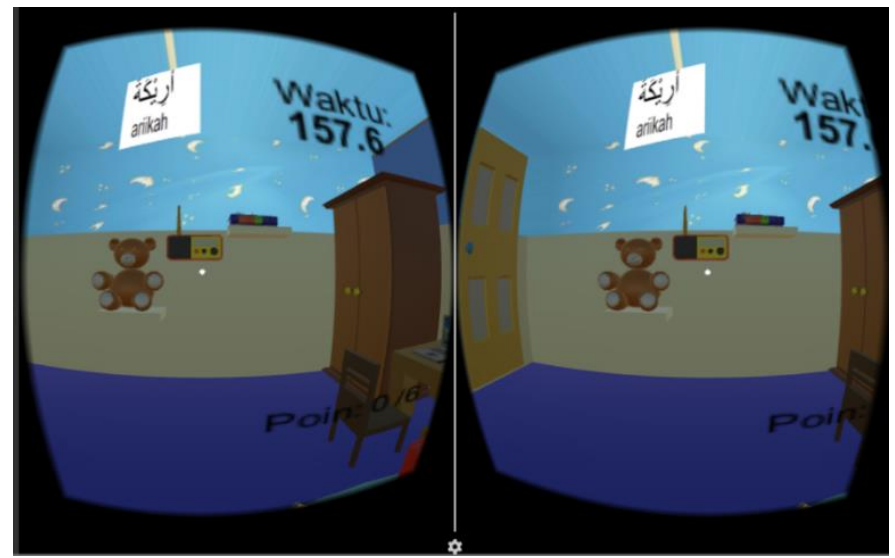

Gambar 5. Tampilan Uji Mencari dan Menemukan Benda Pada Ruang Kamar Tidur Menggunakan Bahasa Arab

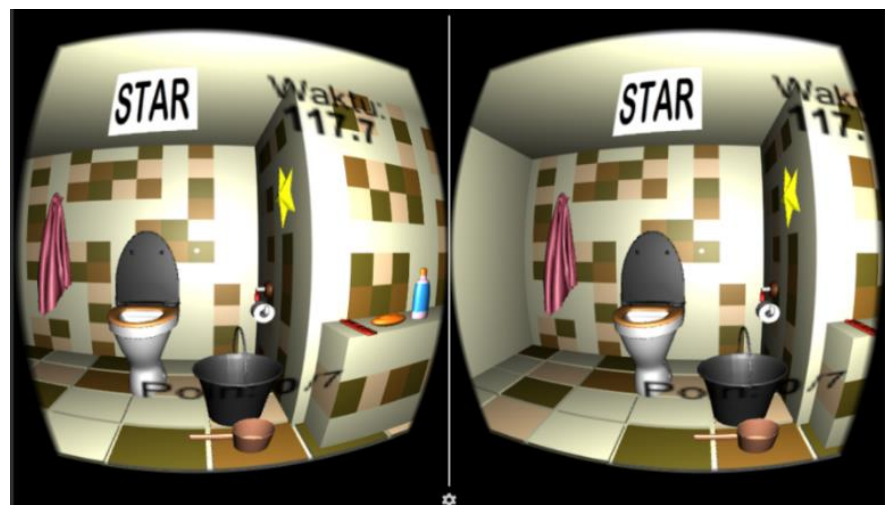

Gambar 6. Tampilan Uji Mencari dan Menemukan Benda Pada Ruang Kamar Mandi Menggunakan Bahasa Inggris

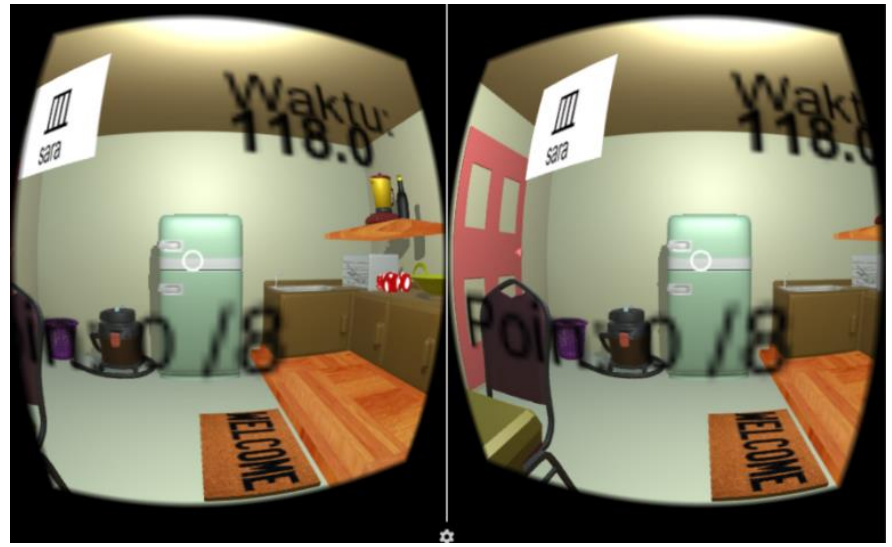

Gambar 7. Tampilan Uji Mencari dan Menemukan Benda Pada Ruang Dapur Tidur Menggunakan Bahasa Jepang

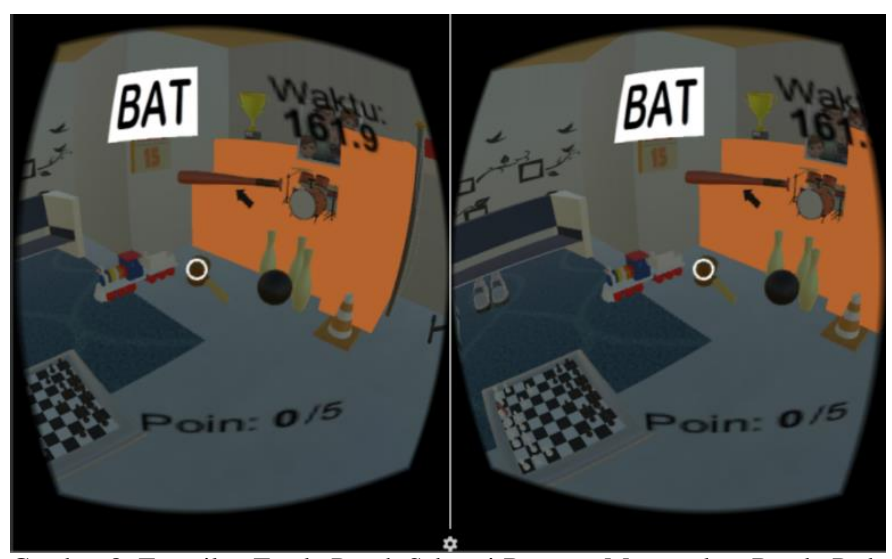

Gambar 8. Tampilan Tanda Panah Sebagai Bantuan Menemukan Benda Pada Ruang Keluarga atau Ruang Tamu Menggunakan Bahasa Inggris

\section{B. Pengujian Non-Fungsionalitas}

Pengujian non-fungsionalitas ini dilakukan oleh sebelas responden. Kemudian setiap responden mengisi kuesioner yang sudah disediakan. Metode kuesioner yang digunakan adalah dengan metode skala lakert yaitu metode pengukuran yang digunakan untuk mengukur sikap, pendapat dan persepsi seseorang atau kelompok orang tentang fenomena sosial [12]. Jawaban dari kuesioner yang digunakan memiliki skala 6 dengan pemberian skor seperti pada Tabel 4.

Tabel 4

Pemberian Skor Jawaban

\begin{tabular}{cc}
\hline \hline Keterangan & Skor \\
\hline Sangat tidak setuju & 1 \\
Tidak setuju & 2 \\
Kurang Setuju & 3 \\
Cukup Setuju & 4 \\
Setuju & 5 \\
Sangat Setuju & 6 \\
\hline \hline
\end{tabular}

Untuk menganalis hasil kuesioner yang diisi oleh responden digunakan rumus untuk mengetahui jumlah hasil nilai setiap pertanyaan sebagai berikut

$$
\text { skor tiap indikator }=\sum_{i=1}^{\mathrm{n}} T \times P i
$$

dimana $n$ adalah skor jawaban maksimal, $T$ adalah jumlah responden yang memilih jawaban $P_{i}$, dan $P_{i}$ adalah skor jawaban ke- $i$ [12].

Setelah jumlah hasil nilai diketahui, maka akan diketahui tingkat persetujuan responden dari Rating Scale setiap bobot 
skor dimana diperlukan penghitungan skor ideal dari semua bobot skor. Skor ideal dapat diketahui dengan cara mengkalikan skor jawaban tertinggi atau maksimal dengan jumlah responden [12]. Skor jawaban tertinggi adalah 6 yang dapat dilihat pada Tabel 4 dan jumlah responden adalah sebelas. Sehingga Rating Scale dapat dilihat pada Tabel 5.

Tabel 5.

\begin{tabular}{cc}
\multicolumn{2}{c}{ Tabel 5. } \\
\hline \hline Rating Scale \\
\hline Nilai Jawaban & Skala \\
$46-66$ & Sangat Setuju \\
$45-55$ & Setuju \\
$34-44$ & Cukup Setuju \\
$23-33$ & Kurang Setuju \\
$12-22$ & Tidak Setuju \\
$0-11$ & Sangat Tidak Setuju \\
\hline \hline
\end{tabular}

Pengujian non-fungsionalitas ini bertujuan untuk mengetahui kenyamanan antarmuka menu, kemiripan objek, kegunaan informasi, perfoma sistem, kenyamanan penggunaan aplikasi, dan perasaan immersive yang dirasakan pengguna. Hasil kuesioner responden akan dijabarkan pada rekapitulasi pada Tabel 6.

Tabel 6.

Rekapitulasi Hasil Uji Coba Non-Fungsional

\begin{tabular}{|c|c|c|c|}
\hline No & Penilaian & Indikator & Hasil \\
\hline 1 & Antarmuka & $\begin{array}{l}\text { Kenyamanan antarmuka } \\
\text { menu }\end{array}$ & $\begin{array}{l}57 \text { (sangat } \\
\text { setuju) }\end{array}$ \\
\hline \multirow[t]{8}{*}{2} & Kemiripan Objek & $\begin{array}{l}\text { Kemiripan objek di } \\
\text { Ruang Kamar }\end{array}$ & 55 (setuju) \\
\hline & & Kemiripan objek di & 60 (sangat \\
\hline & & Ruang Kamar Mandi & setuju) \\
\hline & & Kemiripan objek di Dapur & $\begin{array}{c}60 \text { (sangat } \\
\text { setuju) }\end{array}$ \\
\hline & & Kemiripan objek di & 60 (sangat \\
\hline & & Ruang Tamu atau Ruang & setuju) \\
\hline & & Keluarga & \\
\hline & Hasil Penilaian Ke & iiripan Objek & 58,75 (sangat \\
\hline \multirow[t]{4}{*}{3} & $\begin{array}{l}\text { Kegunaan } \\
\text { Informasi }\end{array}$ & Kejelasan teks informasi & $\begin{array}{l}58 \text { (sangat } \\
\text { setuju) }\end{array}$ \\
\hline & & Kejelasan suara audio & $\begin{array}{l}56 \text { (sangat } \\
\text { setuju) }\end{array}$ \\
\hline & & $\begin{array}{l}\text { Menambah pengetahuan } \\
\text { nama suatu benda dalam } \\
\text { bahasa asing }\end{array}$ & $\begin{array}{l}58 \text { (sangat } \\
\text { setuju) }\end{array}$ \\
\hline & Hasil Penilaian Ke & unaan Informasi & $\begin{array}{l}57,33 \text { (sangat } \\
\text { setuju) }\end{array}$ \\
\hline 4 & Performa Sistem & Real time rendering & $\begin{array}{l}56 \text { (sangat } \\
\text { setuju) }\end{array}$ \\
\hline 5 & Realitas Virtual & Perasaan immersive & $\begin{array}{l}56 \text { (sangat } \\
\text { setuju) }\end{array}$ \\
\hline
\end{tabular}

\begin{tabular}{lllc}
\hline \hline 6 & $\begin{array}{l}\text { Kenyamanan } \\
\text { Penggunaan }\end{array}$ & $\begin{array}{l}\text { Kenyamanan dalam } \\
\text { menggunakan aplikasi }\end{array}$ & 52 (setuju) \\
\hline \hline
\end{tabular}

\section{KESIMPULAN}

Berdasarkan hasil uji coba fungsionalitas, aplikasi berhasil dibangun sesuai rancangan. Sedangkan berdasarkan kuesioner, kenyamanan antarmuka mencapai $86,36 \%$ (responden sangat setuju, dengan nilai 57 dari 66), kemiripan objek mencapai $89,01 \%$ (responden sangat setuju, dengan nilai rata-rata 58,75 dari 66), kegunaan informasi mencapai 86,86\% (responden sangat setuju, dengan nilai rata-rata 57,33 dari 66), performa sistem mencapai nilai $84,85 \%$ (responden sangat setuju, dengan nilai 56 dari 66), perasaan immersive mencapai nilai $84,85 \%$ (responden sangat setuju, dengan nilai 56 dari 66), kenyamanan penggunaan mencapai $78,78 \%$ (responden setuju, dengan nilai 52 dari 66).

\section{DAFTAR PUSTAKA}

[1] A. T. Dina and S. I. Ciornei, "Teaching Less Widely Used Languages with Qualitative Multimedia Resources," Procedia - Soc. Behav. Sci., vol. 128, pp. 246-250, Apr. 2014.

[2] L. Nathania, "Ini Bahasa yang Paling Banyak Digunakan di Dunia, Bahasa Inggris Nomor Tiga," Tribunnews.com. .

[3] S. A, PEMBELAJARAN BAHASA ASING. Universitas Pendidikan Indonesia Fakultas Pendidikan Bahasa dan Sastra.

[4] T. Mazuryk, Virtual Reality History, Applications, Technology and Future. Institute of Computer Graphics Vienna University of Technology.

[5] dan S. S. P. Bhawar, N. Ayer, "Methodology to Create Optimized 3D Models Using Blender for Android Devices," in Technology for Education (T4E), 2013 IEEE Fifth International Conference, 2013, pp. 139-142.

[6] R. Pérez Fernández and V. Alonso, "Virtual Reality in a shipbuilding environment," Adv. Eng. Softw., vol. 81, pp. 30-40, Mar. 2015.

[7] I. Hamilton, "Learn Spanish or German in House of Languages on Gear VR," UploadVR, Nov-2015. .

[8] S. Id, "Samsung Gear VR Harga - Samsung Gear VR Spesifikasi | Indonesia," 2017. [Online]. Available: http://www.samsung.com/id/wearables/gear-vr-r322/. .

[9] J. W. Wirawan, "Mencermati Pengajaran Bahasa Asing Pada Anak Usia Dini di Indonesia," BBC Indonesia, 2017. [Online]. Available: http://www.bbc.com/indonesia/majalah/2015/08/150821_majalah_p endidikan_tk.

[10] M. Dikiria, "Permainan Edukatif Sebagai Media Belajar Anak Usia Dini," maya, 2011. .

[11] R. Hidayat, "Review Google Cardboard," DroidLime.com, 2015.

[12] A. Movies, "Skala Likert," Academia, p. 2, 2016. 